\title{
Selected haematological and biochemical indicators in different breeds of rabbits
}

\author{
Miloslav Martinec ${ }^{1}$, Helena Härtlová ${ }^{2}$, Darina Chodová1, Eva Tůmová ${ }^{1}$, Alena Fučíková \\ ${ }^{1}$ Czech University of Life Sciences Prague, Faculty of Agrobiology and Natural Resources, \\ Department of Animal Husbandry, Prague, Czech Republic \\ ${ }^{2}$ Czech University of Life Sciences Prague, Faculty of Agrobiology and Natural Resources, \\ Department of Veterinary Science, Prague, Czech Republic \\ Received November 9, 2010 \\ Accepted July 16, 2012
}

\begin{abstract}
The aim of the study was to evaluate differences in haematological and biochemical indicators in young rabbits of breeds embedded in the Czech genetic resources. Seven breeds (Moravian Blue, Czech Spotted, Czech Solver, Czech White, Czech Red, Moravian White of Brown Eyes and Czech Black Guard Hairs) represented by six males of each breed were used. Weaned rabbits were fattened under identical conditions till the age of 91 days. Haematological values were measured by using automatic analyzer; biochemical indicators were determined photometrically. From the haematological indicators, mean cell volume was significantly $(P \leq 0.05)$ higher in Czech Black Guard Hairs (83.00 fl) and the lowest (73.75 fl) in Czech Red. Significantly higher $(P \leq 0.05)$ concentration of haemoglobin $\left(143.3 \mathrm{~g} \cdot \mathrm{l}^{-1}\right)$ was recorded in Czech Spotted; values of 125.6 and $123.4 \mathrm{~g} \cdot \mathrm{l}^{-1}$ were found in Czech White and Czech Black Guard Hairs, respectively. From the biochemical indicators, cholesterol and triacylglycerols significantly differed in rabbit breeds. Significantly $(P \leq 0.05)$ higher level of cholesterol $\left(3.16 \mathrm{mmol} \cdot 1^{-1}\right)$ was determined in Moravian Blue, decreasing with body size in other breeds. Significant correlations of 0.390 were determined between live weight and serum cholesterol content. Significantly different $(P \leq$ 0.05 ) content of triacylglycerols was found in Czech White and Moravian White of Brown Eyes ( 1.30 vs. $0.75 \mathrm{mmol}^{-1^{-1}}$ ). Our results showed for the first time haematological and biochemical indicators in rabbits from Czech genetic resources and the results revealed that some of these variables could be affected by the rabbit genotype.
\end{abstract}

Genetic resources, blood, haemoglobin, cholesterol, triacylglycerols, correlations

Biochemical and haematological examinations provide valuable information on objective assessment of health status, in order to detect health disorders or for monitoring stress factors already at preclinical stage (Hint on et al. 1982). Changes in physiological biochemical and haematological values can also be used as indicators of welfare in rabbit breeding (Hoy and Verga 2006). Biochemical and haematological values may be influenced by a number of environmental factors, such as feed components and animal management. Differences between rabbit genotypes in biochemical and haematological values were not studied in details with the exception of status in Watanabe heritable hyperlipaemic rabbits (Kondo and Watanabe 1975), and similar model rabbits (Kurosawa et al. 1995).

The effect of rabbit genotype on blood picture and serum biochemical indicators were demonstrated in crossbreeds of Californian, Checkered giant and New Zealand White (NZW) rabbits. Crossbred rabbits had significantly higher values of haemoglobin, erythrocyte number and leukocyte number compared to NZW rabbits (Burnett et al. 2006). Similarly, Chineke et al. (2006) described rabbit genotype differences for mean values leukocyte number and haematocrit in hybrids of breeds NZW, Chinchilla and Dutch belted, however, all genotypes used in the study were similar in haemoglobin, erythrocyte number and mean cell volume (MCV). Jurčík et al. (2007) stated significant differences in haemoglobin, total protein and urea content in transgenic rabbits compared with nontransgenic rabbits.

The aim of this study was to evaluate differences in haematological and biochemical indicators in young rabbits of different breeds embedded in the Czech genetic resources.

Address for correspondence:

Eva Tủmová

Department of Animal Husbandry

Czech University of Life Sciences

Kamýcká 129, 16521 Prague 6-Suchdol

Czech Republic

Phone: +420224383048

Fax: +420224383065

E-mail: tumova@af.czu.cz

http://actavet.vfu.cz/ 


\section{Materials and Methods}

The experiment was carried out on breeds included in the Czech Program of Conservation and Development of Genetic Resources and Agrobiodiversity. Seven breeds of Moravian Blue (MB), Czech Spotted (CS), Czech Solver (CB), Czech White (CW), Czech Red (CR), Moravian White of Brown Eyes (MW) and Czech Black Guard Hairs $(\mathrm{CH})$ rabbits with 16 weaned rabbits (males and females ratio 1:1) per breed were used. The rabbits were fattened from 42 till 91 days of age under identical conditions in commercial wire cages for two rabbits, with the floor density of $0.09 \mathrm{~m}^{2}$ per rabbit. The rabbits were fed pelleted feed mixture with the following nutrient content: crude protein $184 \mathrm{~g} / \mathrm{kg}$, crude fibre $169 \mathrm{~g} / \mathrm{kg}$, starch $117 \mathrm{~g} / \mathrm{kg}$ and fat $36.8 \mathrm{~g} / \mathrm{kg}$. Both water and feed were available ad libitum. Environmental conditions were maintained throughout the fattening period as follows: temperature of $16-17^{\circ} \mathrm{C}$, relative humidity of $65 \%$ and 12 -h light regime. The rabbits were fasted (after fattening period) overnight and slaughtered in the experimental slaughterhouse. No rabbit showed any clinical signs of disease and their body condition was good. Haematological and biochemical indicators were evaluated in rabbits at the age of 92 days. Blood was sampled from 42 rabbits (six males of the average weight of each breed) during slaughtering from the jugular vein; two samples of blood from each rabbit, one containing K,EDTA for haematology, and one for biochemical tests collected into tubes without anticoagulant agent. The blood serum after centrifugation of samples $\left(1000 \mathrm{~g}\right.$ for $10 \mathrm{~min}$ ) was stored at $-70^{\circ} \mathrm{C}$ until analysis.

Haematological examination was carried out on samples of blood stabilized within $24 \mathrm{~h}$ after removal (samples were stored at $4{ }^{\circ} \mathrm{C}$ ) using automatic haematological analyzer Coulter model ZF (Coulter Electronics Ltd., UK). Erythrocyte and leukocyte number, haemoglobin concentration and haematocrit were determined. On the basis of erythrocyte and haematocrit values MCV was calculated. Biochemical indicators in serum as the total protein (TP), albumin, urea, glucose, cholesterol, triacylglycerols (TAG) and non-esterifed fatty acids (NEFA) were determined photometrically in a spectrophotometer Libra S 22 (Biochrom Ltd., UK) by using a standard commercial kits (Randox Laboratories Ltd., Crumlin, UK).

Statistical analysis was performed using the program SAS (SAS Institute Inc., 2003). The results were processed by one-way ANOVA, all values were expressed as mean \pm SE. Differences between breeds were tested by Duncan test at the level of significance $P \leq 0.05$. Relationship between serum biochemistry characteristics and live weight was evaluated by estimating Pearson correlation coefficient.

\section{Results}

Results of haematological indicators monitored in different rabbit breeds are listed in Table 1. Breed-related significant $(P \leq 0.05)$ differences of haematological values were shown in MCV and haemoglobin values. The values of MCV were the highest in $\mathrm{CH}$ $(83.00 \mathrm{fl})$ and the lowest in CR (73.75 fl). In other breeds no significant difference was found and the value of MCV ranged from 77.5 to $80.5 \mathrm{fl}$. Haemoglobin concentrations were in the range from 123.4 to $143.3 \mathrm{~g} \cdot \mathrm{l}^{-1}$. The highest value of haemoglobin was recorded in the CS. The significant difference $(P \leq 0.05)$ in haemoglobin concentration was recorded

Table 1. Values of haematological indicators in rabbit breeds of Czech genetic resources

\begin{tabular}{|c|c|c|c|c|c|c|c|}
\hline \multirow[t]{2}{*}{ Variable } & \multicolumn{7}{|c|}{ Breed } \\
\hline & MB & $\mathrm{CS}$ & $\mathrm{CB}$ & $\mathrm{CW}$ & CR & MW & $\mathrm{CH}$ \\
\hline Erythrocytes & 6.38 & 6.68 & 6.33 & 5.83 & 6.50 & 6.20 & 5.77 \\
\hline$\left(\mathrm{T} \cdot \mathrm{l}^{-1}\right)$ & \pm 0.68 & \pm 0.30 & \pm 0.40 & \pm 0.18 & \pm 0.35 & \pm 0.53 & \pm 0.16 \\
\hline Leukocytes & 2.62 & 3.60 & 2.74 & 2.06 & 2.44 & 3.68 & 2.52 \\
\hline$\left(\mathrm{G} \cdot \mathrm{l}^{-1}\right)$ & \pm 0.87 & \pm 0.76 & \pm 0.75 & \pm 0.31 & \pm 0.57 & \pm 0.73 & \pm 0.71 \\
\hline \multirow[t]{2}{*}{ Mean cell volume (fl) } & $78.6^{\mathrm{ab}}$ & $78.75^{\mathrm{ab}}$ & $80.5^{\mathrm{ab}}$ & $80.25^{\mathrm{ab}}$ & $73.75^{\mathrm{b}}$ & $77.5^{\mathrm{ab}}$ & $83.00^{\mathrm{a}}$ \\
\hline & \pm 5.52 & \pm 1.75 & \pm 3.0 & \pm 3.25 & \pm 3.27 & \pm 3.0 & \pm 2.0 \\
\hline \multirow[t]{2}{*}{ Haemoglobin $\left(\mathrm{g} \cdot \mathrm{l}^{-1}\right)$} & $132.6^{\mathrm{abc}}$ & $143.3^{\mathrm{a}}$ & $139.2^{\mathrm{ab}}$ & $125.6^{\mathrm{bc}}$ & $131.0^{\mathrm{abc}}$ & $134.8^{\mathrm{abc}}$ & $123.4^{\mathrm{c}}$ \\
\hline & \pm 10.7 & \pm 2.9 & \pm 6.9 & \pm 3.1 & \pm 5.6 & \pm 5.2 & \pm 2.9 \\
\hline \multirow[t]{2}{*}{ Haematocrit $\left(1 \cdot 1^{-1}\right)$} & 49.48 & 53.04 & 51.62 & 46.58 & 48.44 & 46.92 & 47.88 \\
\hline & \pm 3.48 & \pm 2.73 & \pm 3.22 & \pm 1.42 & \pm 1.25 & \pm 6.54 & \pm 1.82 \\
\hline
\end{tabular}

a, b, $\mathrm{c}$ means in the same row with different superscripts differ $(P \leq 0.05)$

Breed: MB - Moravian Blue, CS - Czech Spotted, CB - Czech Solver, CW - Czech White, CR - Czech Red, MW - Moravian White and CH - Czech Black Guard Hairs rabbit 
Table 2. Values of biochemical indicators in rabbit breeds of Czech genetic resources and correlation coefficients between live weight and biochemical indicators

\begin{tabular}{lcccccccc}
\hline Variable & & & \multicolumn{3}{c}{ Breed } & & \multicolumn{2}{c}{$r$} \\
& MB & CS & CB & CW & CR & MW & CH & \\
\hline Total protein $\left(\mathrm{g} \cdot 1^{-1}\right)$ & 70.66 & 65.40 & 64.71 & 67.17 & 62.43 & 63.99 & 60.28 & 0.259 \\
& \pm 5.61 & \pm 4.31 & \pm 4.29 & \pm 1.62 & \pm 6.86 & \pm 6.29 & \pm 6.56 & $(0.111)$ \\
Albumin $\left(\mathrm{g} \cdot \mathrm{l}^{-1}\right)$ & 37.99 & 43.30 & 38.43 & 43.78 & 42.15 & 54.38 & 40.29 & 0.177 \\
& \pm 4.31 & \pm 6.32 & \pm 5.78 & \pm 7.11 & \pm 6.67 & \pm 4.03 & \pm 5.99 & $(0.280)$ \\
& 5.19 & 3.73 & 4.29 & 3.72 & 4.97 & 5.27 & 5.08 & 0.178 \\
Urea $\left(\mathrm{mmol} \cdot \mathrm{l}^{-1}\right)$ & \pm 2.37 & \pm 0.74 & \pm 1.47 & \pm 0.85 & \pm 0.95 & \pm 1.44 & \pm 1.10 & $(0.218)$ \\
& 4.97 & 5.63 & 4.84 & 3.94 & 4.29 & 5.16 & 5.01 & 0.142 \\
Glucose $\left(\mathrm{mmol} \cdot \mathrm{l}^{-1}\right)$ & \pm 1.33 & \pm 1.38 & \pm 2.59 & \pm 1.41 & \pm 6.67 & \pm 1.81 & \pm 2.25 & $(0.386)$ \\
& $3.16^{\mathrm{a}}$ & $1.97^{\mathrm{b}}$ & $1.83^{\mathrm{b}}$ & $2.36^{\mathrm{ab}}$ & $1.46^{\mathrm{b}}$ & $2.03^{\mathrm{b}}$ & $1.73^{\mathrm{b}}$ & 0.390 \\
Cholesterol $\left(\mathrm{mmol} \cdot \mathrm{l}^{-1}\right)$ & \pm 0.80 & \pm 0.50 & \pm 0.56 & \pm 0.94 & \pm 0.59 & \pm 0.65 & \pm 0.60 & $(0.012)$ \\
& $0.91^{\mathrm{ab}}$ & $0.89^{\mathrm{ab}}$ & $1.19^{\mathrm{ab}}$ & $1.30^{\mathrm{a}}$ & $0.94^{\mathrm{ab}}$ & $0.75^{\mathrm{b}}$ & $1.12^{\mathrm{ab}}$ & 0.115 \\
Triacylglycerols $\left(\mathrm{mmol} \cdot \mathrm{l}^{-1}\right)$ & \pm 0.15 & \pm 0.18 & \pm 0.29 & \pm 0.27 & \pm 0.11 & \pm 0.12 & \pm 0.59 & $(0.477)$ \\
& 1.17 & 0.95 & 0.75 & 0.85 & 0.84 & 0.82 & 0.69 & -0.125 \\
NEFA $\left(\mathrm{g} \cdot \mathrm{l}^{-1}\right)$ & \pm 0.40 & \pm 0.37 & \pm 0.37 & \pm 0.41 & \pm 0.11 & \pm 0.41 & \pm 0.27 & $(0.439)$ \\
& $2603^{\mathrm{a}}$ & $2280^{\mathrm{b}}$ & $2486^{\mathrm{ab}}$ & $2617^{\mathrm{a}}$ & $1840^{\mathrm{c}}$ & $2250^{\mathrm{b}}$ & $1887^{\mathrm{c}}$ & \pm 102
\end{tabular}

${ }^{\mathrm{a}, \mathrm{b}, \mathrm{c}}$ means in the same row with different superscripts differ $(P \leq 0.05)$,

$\mathrm{r}$ - correlation coefficient between live weight and a indicator, significance of correlations is in a bracket, NEFA

- non-esterifed fatty acids

Breed: MB - Moravian Blue, CS - Czech Spotted, CB - Czech Solver, CW - Czech White, CR - Czech Red, MW - Moravian White and $\mathrm{CH}$ - Czech Black Guard Hairs rabbit

only in $\mathrm{CW}$, and $\mathrm{CH}$. The values of erythrocytes, leukocytes and haematocrit were found in physiological values and were not significantly $(P \leq 0.05)$ affected by the genotype of rabbit. The results of biochemical examination of serum in different rabbit breeds are shown in Table 2. Concentration of cholesterol and TAG was significantly different $(P \leq 0.05)$. The highest concentration of cholesterol was determined in the large breed of MB (3.16 mmol. $\left.\mathrm{l}^{-1}\right)$, whereas in other rabbit breeds cholesterol content did not significantly decrease with body size. Significant difference $(P<0.05)$ in the TAG content was found in $\mathrm{CW}$ and MW (1.30 vs. $\left.0.75 \mathrm{mmol} \cdot \mathrm{l}^{-1}\right)$; other breeds did not show a significant difference. Other biochemical indicators such as glucose, NEFA, TP, albumin and urea did not differ between rabbit breeds. Correlation analyses indicated low values between live weight and selected biochemical indicators except for serum cholesterol concentration. This correlation was medium (0.390) and significant (0.012).

\section{Discussion}

Haematological characteristics

In our study, significant differences were not detected in the erythrocyte number. However, Burnett et al. (2006) demonstrated a larger erythrocyte number in rabbit hybrids compared to NZW. This result was probably influenced by heterosis, rather than a breed marker. Leukocyte number was at a lower range of physiological value $\left(2-12 \mathrm{G}^{-1} \mathrm{l}^{-1}\right)$ as reported by Flecknell (2000). Tůmová et al. (2007) stated a higher number of leukocytes $\left(7.02 \mathrm{G}^{-1} \mathrm{l}^{-1}\right)$ in broiler rabbits in similar environmental conditions and feeding. Similar results were found by Hewitt et al. (1989), Burnett et al. (2006) or Archetti et al. (2008). Lower leukocyte number in all rabbit breeds in 
this study presumably might have been connected with lower immune stage of pure breeds, generally known for their lower resistance and viability compared to hybrid rabbits.

Significant differences were found for MCV values in breeds $\mathrm{CR}$ and $\mathrm{CH}$. These breeds did not differ in body size, so MCV might be the breed characteristic. Values of MCV determined in our study were higher than 58-79.6 fl or 52-60 fl reported by Hewitt et al. (1989) and by Archetti et al. (2008), respectively. Our results also confirmed findings of Burnett et al. (2006), who found significant differences in MCV values between rabbit breeds. Content of haemoglobin found in our study was consistent with results of Hewitt et al. (1989) and Archetti et al. (2008). On other side, Tůmová et al. (2007) found lower haemoglobin content $\left(76.2-73.0 \mathrm{~g} \cdot 1^{-1)}\right.$ in young broiler rabbit. In our study, haematocrit levels were not affected by rabbit genotype but our results differed from findings of Chineke et al. (2006) who detected significant variation between rabbit breeds.

Biochemical indicators

We did not find significant differences in the TP contents between rabbit breeds. Values of TP were in accordance with results of Kaneko et al. (1997), Rupić et al. (1999), and Burnett et al. (2006). On the contrary, Archetti et al. (2008) found lower values in growing broiler rabbits $\left(32-61 \mathrm{~g} \cdot \mathrm{l}^{-1}\right)$. The albumin levels were not affected by rabbit genotype, our results correspond with the results of Flecknell (2000) and Burnett et al. (2006). Similarly, the blood urea did not vary according to rabbit genotype, the content of urea corresponded to the results of Jurčík et al. (2007) and Archetti et al. (2008). Values of glucose were not significantly different in rabbit breeds, average glucose values were similar to the results reported by Kaneko et al. (1997). Cholesterol content in the examined rabbit breeds corresponded with the range in growing rabbits presented by Burnett et al. (2006) and Javed et al. (2009). However, Kaneko et al. (1997) and Flecknell (2000) indicated the physiological range $0.14-1.86$ and $0.1-2.0 \mathrm{mmol}^{-1} \mathrm{l}^{-1}$, respectively. Large breed $\mathrm{MB}$ had significantly the highest cholesterol level. In CW, cholesterol did not vary from the MB and values obtained in other breeds. Values of TAG in our study were lower than in most references such as Rupić et al. (1999), Corino et al. (2002) and Javed et al. (2009). In our study, significant differences in TAG concentration were found with the highest values in $\mathrm{CW}$ and the lowest in MW. The effect of rabbit breed on TAG content was not described in literature. Results of NEFA were not affected by rabbit genotype, and were higher than those found by Corino et al. (2002) or Rommers et al. (2004). Level of NEFA increases during fasting, higher NEFA levels have been considered as indicators of a negative energy balance (Emery et al. 1992), which may explain the higher levels of NEFA in our experiment after fasting rabbits before slaughtering.

Correlation coefficients between live weight and serum biochemical indicators were low and not significant, only correlations between serum cholesterol level and live weight were medium and significant. The relationship of cholesterol and body size could be influenced by rabbit genotype (Lukefahr et al. 1989; Hernandez et al. 2008). Genetic changes of cholesterol concentration in rabbits were detected by Kurosawa et al. (1985) and Atkinson et al. (1989). Serum cholesterol levels were related to growth and carcass traits also in cattle (Wheeler et al. 1987) and poultry (Wilcox et al. 1963).

Differences in basic haematological and biochemical indicators of rabbit breeds after dozens of generations of pure breeding, characterized by the exterior features, have not been systematically studied. In our study, the effect of rabbit breed was revealed in MCV, haemoglobin, cholesterol and TAG. Significant correlations were found between live weight and serum cholesterol levels. It is evident that rabbit breeds differ in lipid metabolism. 


\section{Acknowledgements}

The study was supported by the Ministry of Agriculture of the Czech Republic (Project No. Q1101A164).

\section{References}

Archetti I, Titterelli C, Cerioli M, Brivio R, Grilli G, Lavazza A 2008: Serum chemistry and haematology values in commercial rabbits: Preliminatory data from industrial farms in northern Italy. Proc $9^{\text {th }}$ World Rabbit Congress, Verona, Italy, 1147-1152

Atkinson JB, Hoover RL, Berry KK, Swift LL 1989: Cholesterol-fed heterozygous Watanabe heritable hyperlipidemic rabbits: a new model for atherosclerosis. Atherosclerosis 78: 123-136

Burnett N, Mathura K, Metivier KS, Holder RB, Brown G, Campbell M 2006: An investigation into haematological and serum chemistry parameters of rabbits in Trinidad. Wld Rabbit Sci 14: 175-187

Chineke CA, Ologun AG, Ikeobi CON 2006: Haematological parameters in rabbit breed and crosses in humid tropics. Pakistan J Biol Sci 9: 2102-2106

Corino C, Mourot J, Magni S, Pastorelli G, Rosi F 2002: Influence of dietary conjugated linoleic acid on growth, meat quality, lipogenesis, plasma leptin and physiological variables of lipid metabolism in rabbits. J Anim Sci 74: $1020-1028$

Emery RS, Liesman JS, Herdt TH 1992: Metabolism of long chain fatty acids in ruminant liver. Anim Nutr Physiol 122: 832-837

Flecknell P 2000: Manual of rabbit medicine and surgery. British Small Animal Veterinary Association, Gloucester, $160 \mathrm{p}$.

Hernandez P, Cesari V, Blasco A 2008: Effect of genetic rabbit lines on lipid content, lypolytic activities and fatty acid composition of hind leg meat and perirenal fat. Meat Sci 78: 485-491

Hewitt CD, Innes DJ, Savory J, Wills MR 1989: Normal biochemical and haematological values in New Zealand White Rabbits. Clin Chem 35: 1777-1779

Hinton M, Jones DRE, Festing MFW 1982: Haematological findings in healthy and diseased rabbits, a multivariate analysis. Lab Anim 16: 123-129

Hoy S, Verga M 2006: Welfare indicators. In: Maertens L, Coudert P (Eds.) Recent Advances in Rabbit Sciences, ILVO, Melle, Belgium: pp.71-74

Javed I, Rahman ZU, Khan MZ., Faqir M, Bilal A, Iqbal I, Javed S, Ijaz A 2009: Antihyperlipidaemic efficacy of Trachyspermum ammi in albino rabbits. Acta Vet Brno 78: 229-236

Jurčík R, Süvegová K, Hanusová E, Massanyi P, Ryban L, Chrenek P 2007: Evaluation of haematological, biochemical and histopathological parameters of transgenic rabbits. J Vet Med A 54: 527-531

Kaneko JJ, Harvey JW, Bruss ML 1997: Clinical biochemistry of domestic animals. $5^{\text {th }}$ ed. Academic Press, San Diego, California, USA, $932 \mathrm{p}$.

Kondo T, Watanabe Y 1975: A heritable hyperlipemic rabbit. Exp Anim 24: 89-94

Kurosawa T, Kusanagi M, Yamasaki Y, Senga Y, Yamamoto T 1995: New mutant rabbit strain with hyperocholesterolemia and atherosclerotic lesions produced by serial inbreeding. Lab Anim Sci 45: 385-392

Lukefahr SD, Nwosu CV, Rao DR 1989: Cholesterol level of rabbit meat and trait relationship among growth, carcass and lean yield performances. J Anim Sci 67: 2009-2017

Rommers JM, Boiti C, Brecchia G, Meijerhof R, Noordhuizen JPTM, Decuypere E, Kemp B 2004: Metabolic adaptation and hormonal regulation in young rabbit does during long-term caloric restriction and subsequent compensatory growth. Anim Sci 79: 255-264

Rupič V, Škrlin J., Mužic S, Šerman V, Stipič N, Bačar-Huskič L 1999: Protein and fats in the serum of rabbits fed different quantities of dried olive cake. Acta Vet Brno 68: 91-98

SAS Institute Inc. 2003: The SAS System for Windows. Release 9.1.3.

Tůmová E, Zita L, Skřivanová V, Fučíková A, Skřivan M, Burešová M 2007: Digestibility of nutrients, organ development and blood picture in restricted and ad libitum fed broiler rabbits. Arch Geflugelk 71: 6-12

Wheeler TL, Davis GW, Stoecker BJ, Harmon CJ 1987: Cholesterol concentration of longissimus muscle, subcutaneous fat and serum of two beef cattle breed types. J Anim Sci 65: 1531-1543

Wilcox FH, Cherms FL, Van Vleck, Harvey WR, Shaffner CS 1963: Estimates of genetic parameters of serum cholesterol level. Poult Sci 42: 37-42 